\title{
The Experience of Personal Time in Alzheimer's Disease
}

\author{
Philippe Thomas \\ University of Limoges, \\ France, Limoges \\ Cyril Hazif-Thomas \\ University Hospital of Brest, \\ France, Bohars
}

\section{Переживание личного времени при болезни Альцгеймера}

\author{
Филипп Томас \\ Университет Лиможа, \\ Франция, Лимож \\ Кирил Хазиф-Томас \\ Университетский региональный госпиталь Бреста, \\ Франция, Боар \\ Corresponding author. E-mail:philippe.thomas.2008@orange.fr
}

Background. Alzheimer's Disease (AD) is a neurodegenerative illness, which occurs with increasing frequency as people age, and is currently a disease beyond curative therapeutic possibilities. While progressive memory impairment is the upfront element associated with the disease, other neurocognitive problems are also associated with it, such as language impairment that tend to degenerate into aphasia. The paper presents singular representations of time in such patients' lived experience, which with the course of the disease gradually move away from the real present around them. In consequence, they live in a bygone era. The dimension of the perceived world implies an anchoring in temporality in the present by using the resources of the past. This becomes impossible with the progression of the cognitive disorders. Multiple psychological tensions result from patient's maladjustment to temporality.

Objective. The article attempts to define the singular experience of the time of the demented patient according to the phases of the disease.

Design. An analysis of the psychological tensions summoned at the various stages of the disease was carried out using a semiotic methodology.

Results. The progression of the disease gives way to another mode of relation to the world, presentism. With its course, emotions can no longer unfold. At first, the patient seeks to increase his grip on the surrounding world, and the internal psychological tensions are accentu- 
ated. Suddenly the world ends up completely escaping him, and catastrophically the internal tensions collapse. The patient slides irreversibly towards regression.

Conclusion. If the emotional intensity of what the patient experiences is enough, he remains engaged in the time of a presence in the world, even if it is distinct from the reality of those around him. When the intensity collapses, the demented patients disengage from it. The caregivers or families who take care of them can understand the mechanisms involved in the patients' experience of time. This allows them to adapt their own behavior. Thus, they limit the risk of misinterpretation and induce certain behavioral disorders linked to their shift from the reality of the patients.

Keywords: Alzheimer's disease; dementia; emotion; lived experience; time.

Краткое введение. Болезнь Альцгеймера (AD) - это нейродегенеративное заболевание, случающееся с возрастающей частотой при увеличении возраста, и в настоящее время находится за рамками лечебных терапевтических возможностей. Первым признаком болезни является прогрессирующее ухудшение памяти, но при $\mathrm{AD}$ возникают и другие нейрокогнитивные проблемы, например, речевое расстройство, имеющее тенденцию переходить в афазию. В статье описаны единичные представления времени в жизненном опыте пациентов с болезнью Альцгеймера, которые с течением болезни постепенно отдаляются от реального настоящего вокруг них. Фактически они живут в давно ушедшей эпохе. Измерение воспринимаемого мира подразумевает привязку к временно́му в настоящем посредством использования ресурсов прошлого. Это становится невозможным при прогрессировании когнитивных расстройств. Многочисленные психологические напряжения возникают в результате неправильного приспособления пациента к темпоральности.

Цель. В статье предпринята попытка определить единичный опыт переживания времени у больных с деменцией в соответствии с фазами заболевания.

Дизайн. Анализ психологических напряжений, вызванных на различных стадиях заболевания, проводился с использованием семиотической методологии.

Результаты. Прогрессирование болезни вызывает другой способ отношения к миру, презентизм. При этом больной уже не может выражать свои эмоции. Сначала пациент стремится усилить свою “хватку” за окружающий мир, и внутреннее психологическое напряжение также усиливается. Но внезапно мир полностью ускользает от него, и внутреннее напряжение катастрофически разрушается. Пациент необратимо скатывается к регрессии.

Вывод. Если эмоциональная интенсивность переживаний пациента достаточна, он остается вовлеченным в жизнь, хотя его восприятие и отличается от реальности окружающих его людей. Когда интенсивность эмоций резко снижается, пациенты с деменцией выпадают из реальности. Ухаживающий персонал или семьи, которые заботятся о больных, могут понять механизмы, задействованные в переживании пациентами времени. Это позволяет им адаптировать свое собственное поведение. Таким образом, уменьшается риск неправильного толкования поведения больных и можно предупредить определенные поведенческие расстройства у пациентов.

Ключевые слова: болезнь Альизеймера; демениия; эмоция; пережитый опыт; время. 


\section{Introduction}

Alzheimer's Disease (AD) is a neurodegenerative illness, which occurs with increasing frequency as people age, and is currently a disease beyond curative therapeutic possibilities. While progressive memory impairment is the upfront element associated with the disease, other neurocognitive problems are also associated with it, language impairment which can degenerate into aphasia in particular (Thomas, Billon, \& Hazif-Thomas, 2018). This illness disturbs memory and alters the singular representations of time in patients (Luria, 1980). Consequently, with the course of the disease a patient gradually moves away from the surrounding reality, in a retrogressive movement. The presence field of a patient refers him to the position he occupies there, to the perspective of his environment and to the decisional course as to a possible practice which could concern him. This presence of the subject in time takes place in two successive movements. The first is related to the body, the other is discursive, which implies an interpretation, the wording of an inner speech to put into words the representation of the time of the world in which he lives. We will assume, within the framework of this reflection on dementia pathology, that the inner speech, as it was previously stated by A. Luria (1979), is a self-addressed voice necessary to fix the sensitive and consolidate the interpretation of the environment (Thomas et al., 2018).

In this context, it is worth presenting a microgenetic model of inner speech (see Figure 1) closely linked to the self (Pąchalska, 2020). Recent findings suggest that AD may be associated with deficient self/non-self differentiation over time despite a relatively intact body image (Bond et al., 2016). According to M. Pąchalska (2020) inner speech appears in relations to the actual type of drive or desire. The text formulated in the inner speech is brought out from the working memory buffer only after the drives and desires empowered by emotions are transformed into logically and spatially comprehensive linguistic and nonlinguistic images. That text may be kept in the buffer of the working memory for some time, ${ }^{1}$ forming the working self and then moved to the long term memory storage (Brown, 2004).

Most of the time it may be only the inner speech taking a form of the internal monologue (talking to the imaginary representation of oneself) or the internal dialogue when an individual talks to an imaginary other person (this may have a relatively abstract nature). It needs to be stressed that the form of internal dialogue may differ from utterances used in a communication act (Miyake, Emerson, Padilla, \& Ahn, 2004). The internal text may be preserved for significant cognitive, emotional of axiotic reasons in the long term memory and starts to be one of the components of the longitudinal (autobiographic) self (Araujo, Kaplan, \& Damasio, 2013).

It is worthy pointing out that inner speech enables the planning of action (Luria, 1973), and precedes making decisions (acts of will) both in trival and important matters. A process of passing from a given drive to recording the text in the working memory

${ }^{1}$ The buffer of working memory keeps the text for about 30 seconds, and even longer off line. It is a so called absolute now (Brown, 2015). 
takes little time due to the effective executive functions and as a rule is realized as outer speech. It usually finishes one of many acts of the inner speech. However, in the case of really significant matters, or while making important and/or difficult choices between goals that are contradictory, the internal monologue may take a stormy form, full of contradictions, recurrences, and hesitations. It need not end with creation of a text that can be passed to the working memory or to the long term memory to become a component of the longitudinal self. It results in putting off decisions, difficulties in making a shift of action, etc. An individual with a healthy brain (without cognitive disorders - including speech - and without emotional impairments), with intact articulatory organs is able to communicate, i. e., externalize his/her inner speech in two ways:

- talking to oneself (self instructions, reprimands or praises);

- talking to others.

In $\mathrm{AD}$ persons with disorders of cognitive and emotional processes inner speech is reduced or absent and does not control behavior. Moreover, their inner speech will not exteriorize as a self-talk or talking to others, and it may become noncommunicative (with language errors). We have no immediate access to inner speech but we are ablle to gather some knowledge (information) about it thanks to nonverbal forms and means of communications such as pictures, photos, pieces of music, pantomime etc.

New brainimage technologies make possible the recording of occurrences of inner speech (Kropotov, 2016; Pąchalska, 2020). Experiments are usually conducted on healthy and fully conscious people. There are also studies that reveal an occurrence of inner speech in patients with minimal consciousness (Clowes, 2007) who were awoken from a postraumatic coma as well as in AD patients (Bond et al., 2016). Modulation of activity during generation of inner speech is frequently in temporal cortex (Shergill et al., 2002) however recent studies show that in these cases most active are: insula and Broca's area (Alderson-Day \& Fernyhough, 2015), which are also activated in the cases of external $\operatorname{speech}^{2}$ (see Figure 1).

Differences in tasks used to evoke inner speech may lead to its various forms. Some may provoke an expanded form of inner speech (both internal monologue and dialogue), others may induce only inner monologue, while those that stimulate verbal thinking may not induce the inner speech (Dolcos \& Albarracin, 2014; Brown, 2004). Self-talk is a pulsing phenomenon, and can range from positive evaluations of the self in the form of self-encouragement, self-compassion, and self-affirmation to negative evaluations in the form of self-criticism, rumination on negative self-aspects, and expressions of inadequacy or worry (Brown, 2002, 2004; Dolcos \& Albarracin, 2014).

This inner speech is altered by dementia and aphasia in the course of the Alzheimer's disease (Langland-Hassan, Faries, Richardson, \& Dietz, 2015; Fama, Hayward, Snider, Friedman, \& Turkeltaub, 2017). The dimension of the perceived world implies an anchoring in temporality in the present using the resources of the past: a lived experience

${ }^{2}$ Appearance of phonological associations in memory may cause internal auditory experiences or inner speech, which is linked to experiencing the voices of others. 
(presentification) (Husserl, 1996). We will see that with the progression of the disease, it gives way to another mode of relation to the world, presentism (Minkowski, 2013), an era where only the present exists.

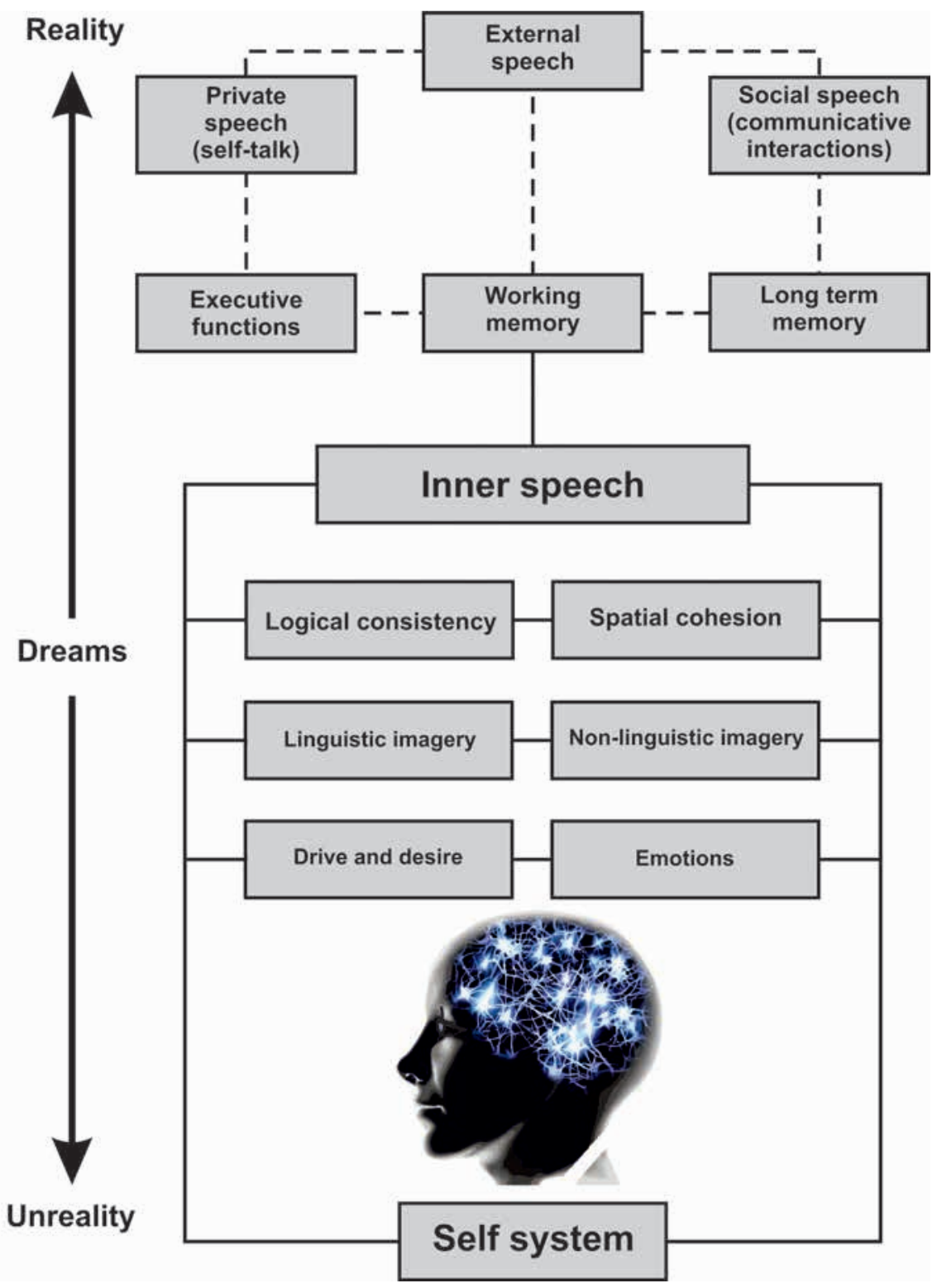

Figure 1. Microgenetic model of inner speech and self system. Processes, which are not (but might be) activated during the inner speech are marked with a broken line. Reprinted from "Inner Speech in MCI and Alzheimer Disease", by M. Pąchalska, 2020, Acta Neuropsychologica, 18 (1), p. 21. Copyright 2020 by the Agencja Wydawnicza Medsportpress. Reprinted with permission 


\section{Reminder on the Tensive Model}

Reflection on the tensive model was introduced by J. Fontanille (1998) and C. Zilberberg (2000) based on analysis of Binswanger's psychopathological space (Binswanger, 1998). The tensive space is defined in two valences which combine the intensity and extensity. By analogy to the definition of the two planes of language (Hjelmslev, 1968), the intensity characterizes the domain of internal, interoceptive feeling, the origin of stimuli coming from the organism itself. It will become the content plane: the interoceptive for the feeling body and the psyche integrating these data into proprioceptive schemes. The plane of the signifiers is the extensity, the external domain in which the emotional intensity can be grasped and developed (extensive deployment): the exteroceptive, the origin of stimuli coming from the external world and the sensor-motility for perceive emotions through the body (Fontanille, 2004; Minkowski, 2013). It will become the plane of expression, the plane of signifiers (Fontanille, 1998).

\section{Intensity and Tensive Extensity}

From the combination of intensity and extensiveness arises the subjective aspect of a situation or event, allowing the taking of a position and of a lived experience of one's own body (Zilberberg, 2000). Intensity refers to an emotional and affective dynamic, intensity to a cognitive dynamic, to the intelligible. These two dimensions come under the semiotics of the construction of the psychic continuum. Intensity and extent are gradual, open, orientable and reversible dimensions, which can be represented on a diagram expressing on the ordinate the gradient of the intensity and on the abscissa that of the extensivity (see Figure 2). Depending on whether the intensity of an event is low or strong, low (diffuse) or high (concentrated), four zones are delimited in this diagram, defining four types of emotions, flat, bright, radiant, empty.

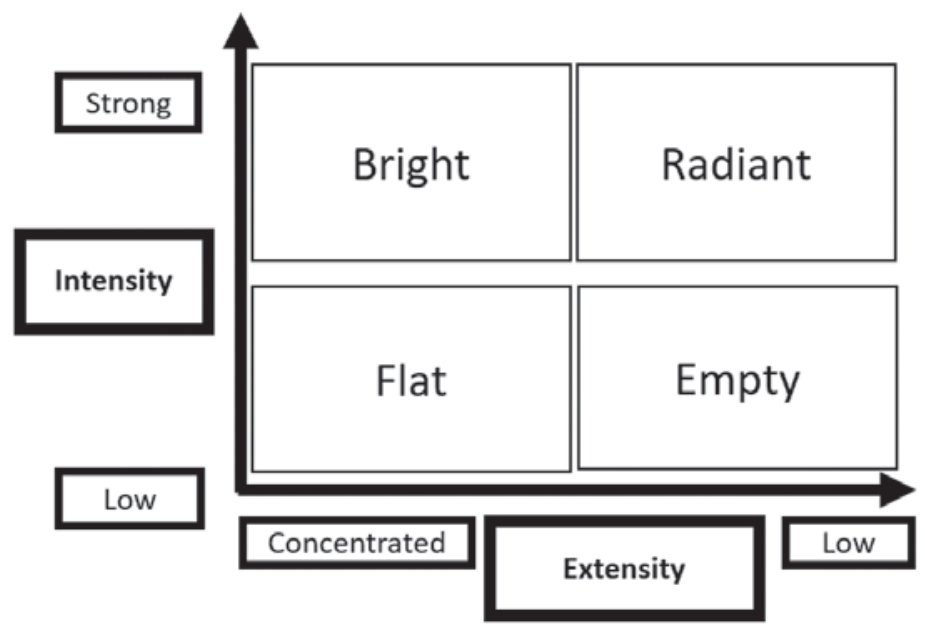

Figure 2. Tensive model. Two valences: Intensity and Extensity.

S o u r c e: Zilberberg, 2000 
An emotionally intense event can be experienced as vivid, overwhelming the psyche, if there is no space to flourish. It will appear to be radiant if the person has the time and space to listen or express themselves. Another event without great emotional mobilization and with a more limited or impossible access to be deployed, for example due to severe disabilities to invest, will be considered flat. A similar event weakly emotionally mobilizing, if a deployment in available space and time potentially exists, will be regarded as a void of interest.

Intensity and extensity combine in the perception of objects and events, as well as with the relative positions of the subject in relation to his environment, sometimes source sometimes target depending on his ability to exercise control. The person can have control over his environment and can experience inner freedom. She can depend on and undergo her environment, losing both her physical and psychological autonomy. Intensity and extensity are the patient's first articulation of his presence in the time of the world.

The intensity and extensity are each broken down into two sub-dimensions, two sub-valences, respectively for the intensity, the tempo with which an event occurs (progressiveness or, on the contrary, violent emergence) and its tone (emotional mobilization strong or peaceful); and for the extensity, the temporality (the length of time to work out what is going on) and the spatiality (the possibility of understanding, of working out, of expressing oneself orally or through actions). Spatiality and temporality represent the possibility of extensive deployment of an emotion. The division of these two intensive sub-valences and of the two extensive sub-valences can be done according to the three dimensions mentioned by Binswanger in relation to psychopathological space, position (the lived event is adapted to the logic of the person, to what the person is or on the contrary it strikes, thwarts), the direction (freedom, opening of the world to oneself or on the contrary prohibited, inaccessibility of it), finally the impetus or the motivation to live what is present (Binswanger, 1998).

\section{The Efficiency Mode}

The mode of efficiency is the way in which an event is likely to enter the field of presence (Zilberberg, 2000), in an inchoative (predictable) or, on the contrary, in an unexpected way, with a brutal tempo, with a limited space and a time for an elaboration. The modes of efficiency thus distinguish the occurring, more generally outside human control and the achieving which presupposes an elaboration, a sustainability and a progression (see Figure 3).

The efficiency mode opposing the happening to the happening allows us to envisage a semiotics of the event (Zilberberg, 2011). The mode of occurring (impromptu irruption of a visitor in the patient's room), referring to the unpredictability of the sense, to the unusual of the situation and when associated with a strong intensity, it is violent, concentrating on a brief temporality the events in terms of extensity. The mode of achieving, on the contrary allows to manage a low intensity with a moderate tempo (the caregiver knocks on the door and slowly enters the room of a patient), with the elements of the intensity manageable, controllable, even familiar. The memory disorders of Alzheimer's disease depriving the patient of access to the past as a resource in the present and to anticipate the future, transforms 


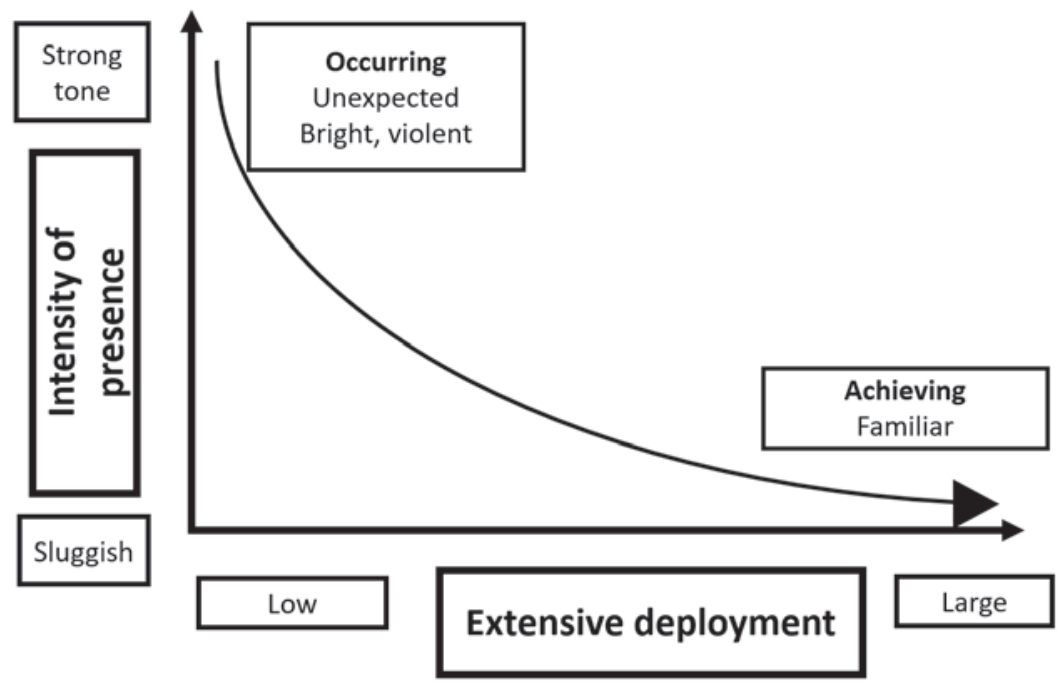

Figure 3. Tensive model. Two modes of efficiency in tension: to arise and to succeed. S o u r c e: Zilberberg, 2000

a banal event into something unexpected that occurs in the field of consciousness (Hazif-Thomas, Thomas, \& Sutter, 1991). The patient no longer has access to an elaboration to project himself in time and space, the extensivity is closed to him. The demented patient is in a presentism (Minkowski, 2013; Thomas, Clément, Hazif-Thomas, \& Leger, 2001).

\section{The Tensive Model and Dementia}

Tensive patterns are greatly disrupted in dementia. The links between the intelligible and the sensitive are untied and unraveled due to cognitive disorders. The sensitive thus tends to impose itself on the psyche of the demented person. The tensive schema still intervenes in memory reminders, memories strongly marked on the emotional level (Fuzzy traces Gist) are more solid than the others (Fuzzy traces Verbatim) (Brainerd \& Reyna, 2001).

\section{Modes of Efficiency and Dementia}

In dementia, the mode of efficiency is involved in the perception of self-image in a mirror. In the twilight of reason, Maisondieu (2011) emphasizes the patient's fear of looking at it. A demented patient lives in a remote time, with representations of the world and himself very far from the present. Brutally discovering one's aged image reflected by the mirror, a way of a too fast happening, is certainly a return to reality, but also a violent and unexpected confrontation. When the patient has a daily toilet in front of the mirror, he sees himself changing, with the insensible transformations as the years go by. It is in the mode of achieving, it does not manifest violence or rejection. 


\section{The Inversion of Tension Patterns and the Disappearance of Space Limits in Dementia}

First, we will look at the dimension of the patient's experience of space depending on whether extensivity is completely open or whether he closes with the course of the disease. He opposes the simple opposites of the open and the closed, and to the extreme the hermetic (the inaccessible) and the gaping (the open without limits).

Figure 4 shows the spatial tensive evolution of a demented elderly person when the disease progresses. We will take the "open" reference position of a person who makes moderate efforts to access a world that is still accessible to him/her, who is normally stressed in daily life, who can add some meaning to the perceived world without great psychological difficulties.

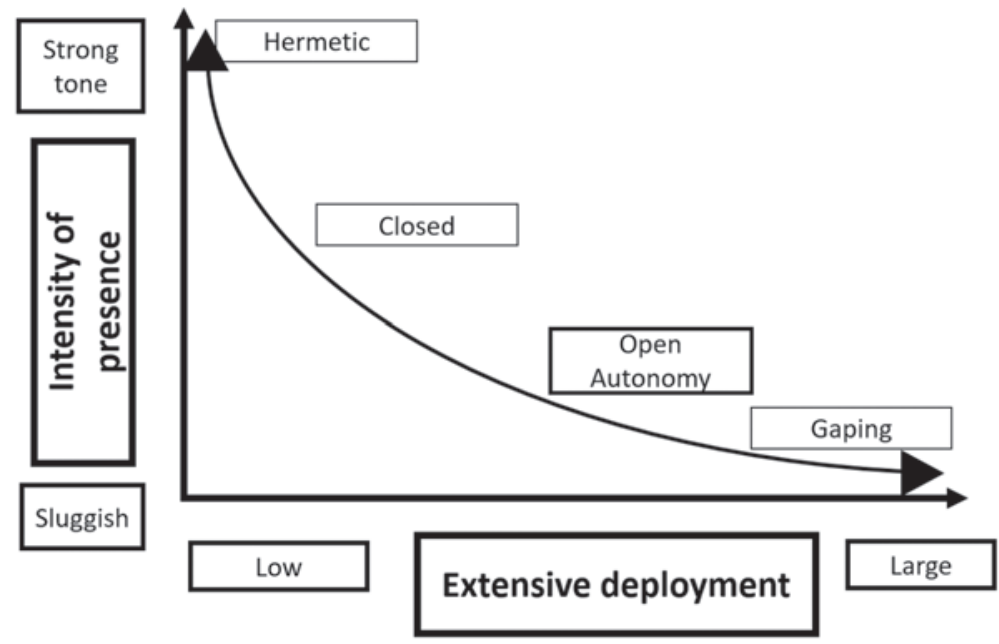

Figure 4. Tensive spatial evolution of a demented person with the progression of the disease. S o u r c e: Zilberberg, 2011

When the disease progresses, the outside world as the sick person perceives it, remains a target to establish his authority over the world. His position in the everyday environment, however, tends to gradually close. He has less easy access to usual services. Shopping becomes less easy, shops in the immediate vicinity are more and more often chosen. The patient is forced to use more energy to support himself and has more difficulty finding help, to maintain both physical and psychological autonomy. Gates to access help or support oneself every day are not always easy to open. The patient intensely seeks to increase a grip on his/her shrinking living territory. He often becomes authoritarian and more rebellious to even small changes.

The patient ends up being dependent on the environment which he no longer controls, which he tries to overcome. He is no longer the source of what he experiences daily, he becomes the target of the external services on which he depends. The world around him becomes a source that provides for his needs, which the patient is far from mastering. When addiction has taken hold, the sick person is exposed to two contradictory movements which 
depend on the conditions of the possibilities of access to the extent of what is necessary for him to live and to express his feelings. Tense or fleeing, these movements often alternate according to the moments or the days. Sometimes, he tenses up on a banal situation, refuses care, violently rejects any relationship. At home, he refuses to see his family or friends, in a retirement home, she refuses to participate in recreational activities. In short, he refuses anything that could relieve his tension. At other times, he tries to flee his situation. He runs away from home; he gets lost in the immediate environment. This position is hermeticism.

Sometimes at the more advanced stage of the disease, the demented person gives up, suddenly letting go of everything that bothers him and he becomes indifferent to any constraint. He neglects the rules of good living and hygiene standards. He has unbridled behavior, unjustified aggressiveness towards others. This is a gaping position, without great tensive intensity but without limit of intensity. The icon for this position is the figure of Tatie Danielle in Etienne Chatiliez's film.

\section{The Inversion of Tension Patterns and the Disappearance of Time Limits in Dementia}

We will examine in this second part the temporal perspectives in the tensive diagrams convened by the progression of the disease. The loss of memory condemns the patient to live in a presentism (Hartog, 2003) which supplants the possibilities of presentification. The past is no help for the present, the future impossible to imagine. The patient is somewhat distant of the present moment, living in a past which is still accessible to him.

We will take as reference position longevity and duration in the sense of Bergson (2012), the length and the enjoyment of a time, which concerns a person still moderately affected (see Figure 5).

The attention required to understand what is happening around the sick person is moderate. The time required to understand his environment and elaborate his perceptions is sufficient so that the demented person is present to himself, adjusted in the time of the world.

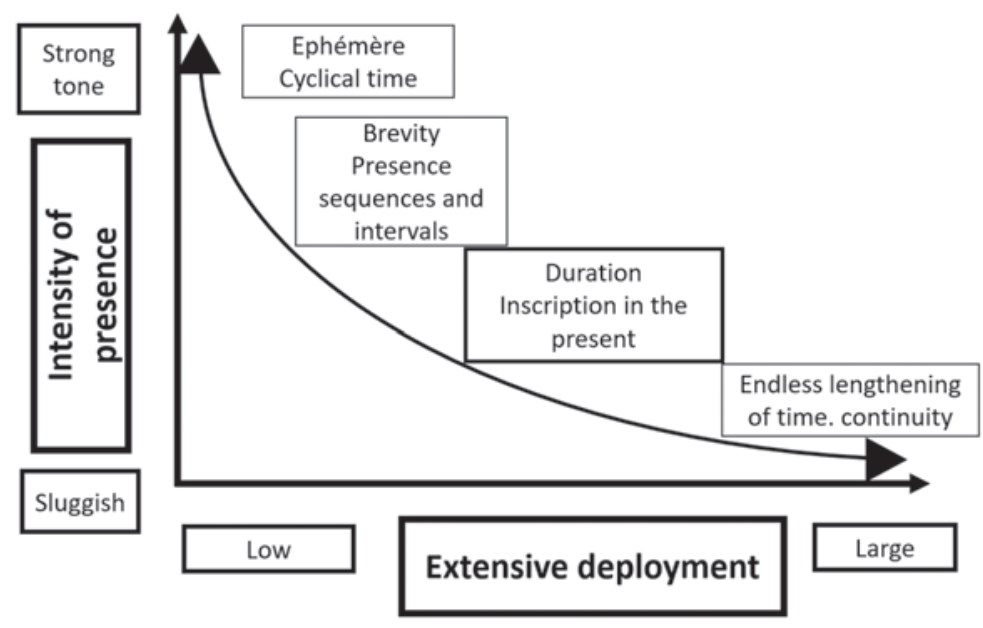

Figure 5. Temporal tensive evolution and progression of the disease.

S o u r c e: Zilberberg, 2011 
As the disease progresses, the times of attention, of presence in the world or in others shorten and divide. The patient is exhausted in mobilizing his attention to grasp an environment that is increasingly complex for him. The emotional intensity is even more marked since his capacity for expression diminishes with aphasia. He expresses himself to those around him with renewed labile interest aroused by a few events or by a visit from a relative or friend. But his attention and interest quickly disappear. His speech becomes impoverished, testifying that with language disorders, the construction of his ideas become sketchy. His presence in time is breaking out. The person seems to live inwardly but briefly, with long intervals of silence and disinterest.

The difficulties encountered by a patient with $\mathrm{AD}$ can be explained by symptom formation according to a microgenetics theory (Pąchalska \& Kaczmarek, 2012), developed in accordance with the syndromological analysis proposed by A. Luria (1979), and symptom formation after brain damage (Brown \& Pąchalska, 2003).

\section{Destabilization of the Models of Conscious Self in AD}

Further development of $\mathrm{AD}$ disease and the associated loss of neurons and neuronal connections causes serious disturbances of working memory. Models of the conscious minimal (working), and longitudinal (autobiographial) self that have existed so far at three hierarchical levels of the brain create in a highly complex "system of systems" characterized by the exchange of information from different systems (Stuss, Rosenbaum, Malcolm, Christiana, \& Keenan, 2005; Pąchalska, 2020).

1. Luria (1973) notes that these models use the functional units of the cortex. The first functional unit of the cortex is the sensory unit. The dark blue-shaded areas are primary zones; medium-shaded are secondary zones; light-shaded areas tertiary zones. Sensory input travels from primary to secondary, then to the tertiary zones, and is thereby elaborated from sensations into symbolic processes. Symbolic processes are in turn translated into intentions in the tertiary motor zones and then into patterns of action in the secondary and primary motor zones. Finally, a speech act is performed with the use of a motor unit, i.e. the second functional unit of the cortex (see Figure 6).

2. Pąchalska (2020) performed studies comprising 76 patients with $\mathrm{AD}$ taking into account Lurian functional units of the cortex. The studies revealed destabilization of a conscious self that occurred in three levels:

- The third level (highest) in which all informations are interpreted in the light of ones own biography, starting with the past and projecting towards the future. In $\mathrm{AD}$ persons processes making possible selfconciousness (ones own existences and action) as well as enabling selfreflection are disrupted. At the same time, transformation of information, modeling world image and the image of oneself is impaired. In consequence, an ability to correctly perceive others and ones own person is severely disturbed. 
- The second level (higher) is concerned with trnsforming basic contents and/or knowledge of the world. Destabilization of this level is caused by a progressive disruption of posterior brain areas (reposible for visuo-spacial functions) as well as the primary motor cortex observed in AD. Maps of the body and of the world are formed at this level based on the information coming from various modalities (visual, auditory, amd haptic) due to the connections between particular areas. The above metioned disruptions result in destabilization of the models and processing of information is delayed, which at first creates difficulties in reacting to incoming stimulus, leading to inability to react after the illness progresses. Hence, the disorders of awareness observed at this level are as a rule specific to a given modality.

- The first level (lower)), concerned with continuous comparison of the existing models with new information, which enables their verification. As a consequence of disruption of many neuronal connections the model does not exist anymore, and all sensations, and experiences must be directly analyzed in the brain. Since working memory (both epizodic and autobiographic) does not exist the brain is not able to model the self, and the patients loses an ability to in an insight into the real world, and drifts in the time, space as well as in his surroundings.

It is in the cortex that perception and action reach the level of conscious decision. The brain forms articulated pictures or representations of what is out there in the world, and of what has been out there in the world, and the play of these images constitutes conscious perception. What is more - and this has only recently begun to be a subject

3. Symbolic processes from the sensory unit are translated into intentions in the tertiary motor zones...

1. Sensory input travels from primary to secondary...
(B) The motor unit

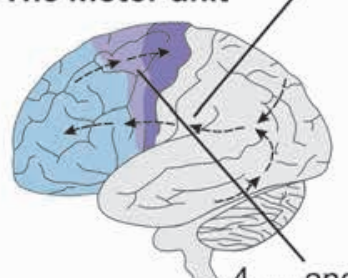

4.... and then into patterns of action in the secondary and primary motor zones

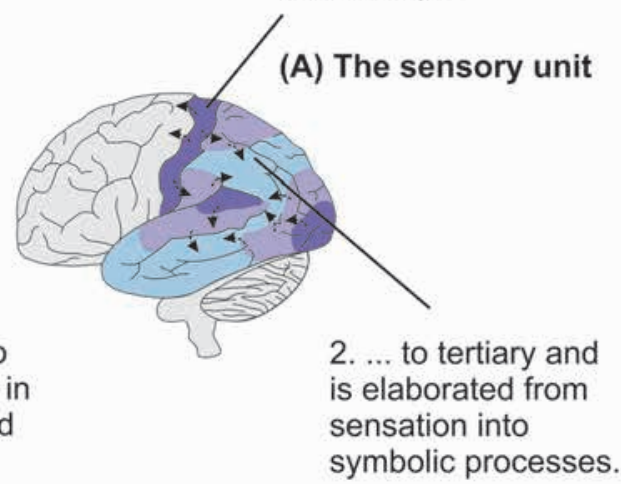

Figure 6. Lurian functional units of the cortex: $(A)$ - the first functional unit of the cortex the sensory unit; $(B)$ - the second functional unit of the cortex - the motor unit. Reprinted from "Alexander Romanovich Luria (1902-1977) and the Microgenetic Approach to the Diagnosis and Rehabilitation of TBI Patients", by M. Pąchalska and B. L. J. Kaczmarek, 2012, Acta Neuropsychologica, 10 (3), p. 345. Copyright 2012 by the Agencja Wydawnicza Medsportpress 
of interest for neuropsychology (Pąchalska, MacQueen, \& Cielebąk, 2018) - the cortex is capable of forming pictures and/or images (see Figure 7) of what might be or could be out there, or could have been, or should have been, and was not.

It is not that hard to form a coherent theory of how the brain forms an image of something that the eyes see or have seen, but it is quite another thing to explain how the "mind's eye" works in terms of brain structure and function. For the present purposes, however, the most important fact about the cerebral cortex is that both perception and action at this stage are characterized by detail, discrimination, and analysis. The reptilian brain sees a large moving object, to be avoided, or seized, or ignored; the paleomammalian brain sees a human figure, producing an affect, positive or negative; the cortex sees features, details, a face, and can put a name to it, or not. The complexity of perception results from the fact that these three images come into existence independently and sequentially, though there is only one perceiver and one object, and the entire process takes milliseconds to complete. The conscious mind, then, typically experiences its perception as a single, simple
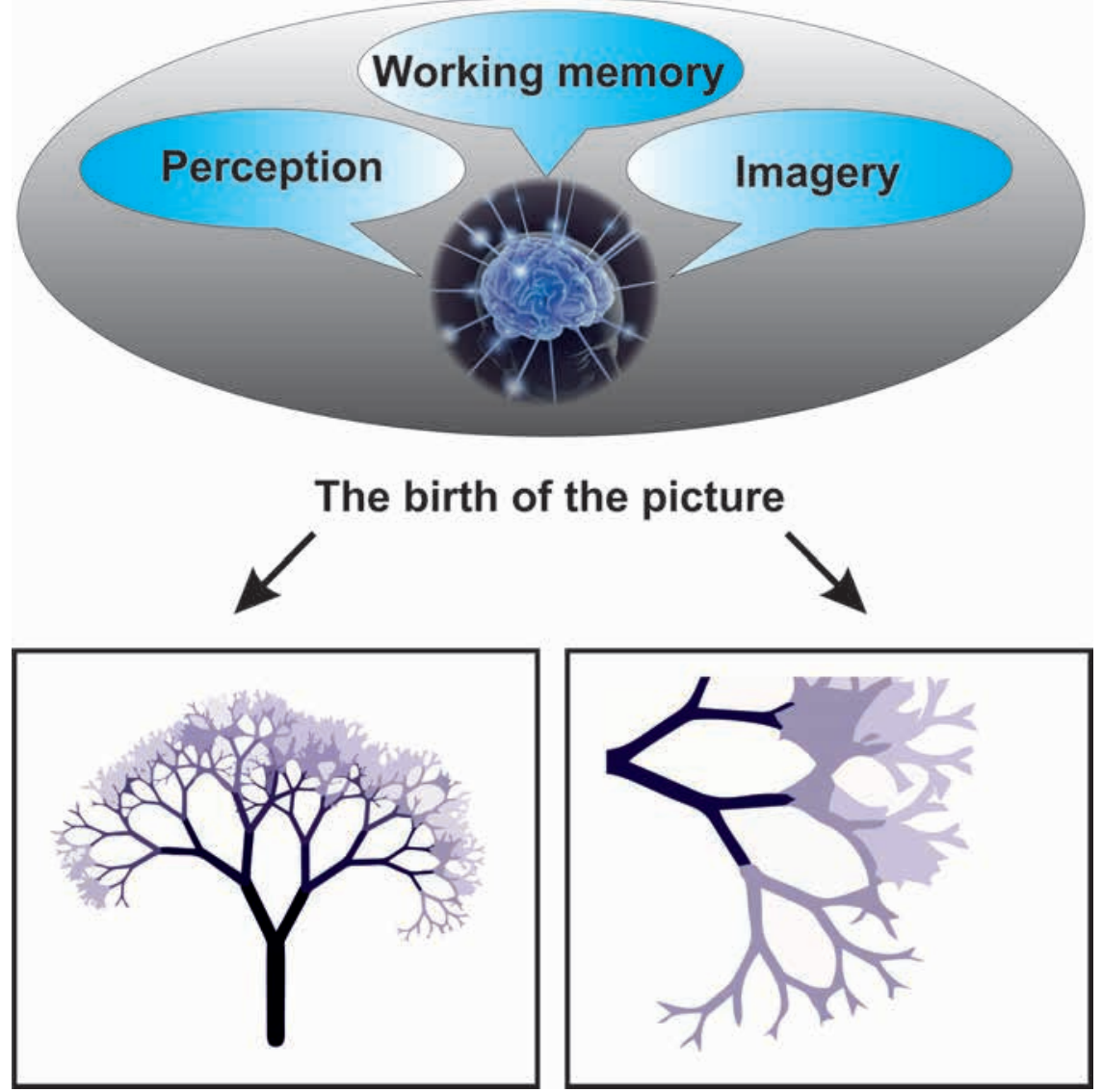

Figure 7. The birth of the picture. Reprinted from "Creative Potentials of Microgenetic Theory", by M. Pąchalska, B. D. MacQueen, and K. Cielebąk, 2018, Acta Neuropsychologica, 16 (2), p. 134. Copyright 2018 by the Agencja Wydawnicza Medsportpress. Reprinted with permission 
act of seeing. According to microgenetic theory, however, this single act is a multi-layered actualization, the tip of an iceberg that floats to the surface and then subsides, containing within itself the traces of all that has gone before, in phylogeny, ontogeny, and microgeny (Pąchalska, MacQueen, \& Brown, 2012).

As objects take on their objective character in a sculpting process constrained by sensory data, time becomes a dimension of the subject-object system, along with space, which expands beyond the arms reach and the immediate visual field. The mind can conceive of places other than "here", and time other than "now". There is past, present, and future, which come into existence as concepts when the fluid before-and-after sequences of limbic time are projected out into the world and fixed to something that at least seems to be objective. This is not to say, of course, that the time of our consciousness is the same as clock time, or even that our ordinary assumptions about the three domains of time (past, present, future) are as natural or self-evident as they may seem. As Brown (2015) continually reminds us, time is a central issue for microgenetic theory, where the crucial point is the duration or "thickness" of the "now". Given that time-space is actually a continuum, the "forward" movement of time is more a psychological than a physical fact. The past is a construct that is created and recreated at each moment of the now; the future is an extrapolation resulting from the experience of a certain "forward" momentum in the resurgence of the "now" over the rapidly receding past.

Thus, from the physical (and metaphysical) point of view, the present is a dimensionless boundary between the fully actualized past, which having exhausted its potential no longer exists, and the potential future, which does not yet exist. When an arrow is shot from a bow at a target, its flight seems a single event, but this is a psychological fact, and not a physical one (Fernyhough, 2013). Whether or not the arrow strikes the target at which it was aimed depends, of course, upon a number of variables: the skill of the archer, the distance, the wind, the movement of the target, etc. At the moment the archer releases the arrow, the range of possible outcomes is still very wide. With the proper video equipment, however, we can break this event down into a series of states, frozen on film, and at each of these "nows" the number of possible trajectories is significantly reduced, as is the number of possible interfering factors. With each successive frame, then, it becomes easier to predict whether or not the arrow will strike the target, and at some point it becomes reasonably easy to predict exactly where it will strike the target. At 100 milliseconds before impact there is no real doubt what is about to happen.

The point of this example is that every mental act is in fact played out in the same way as the flight of this hypothetical arrow, and this is what forms the essence of time as the cortex learns to manipulate it. In fact, though the time in which cortex operates may seem more objective, closer to the fourth dimension of physical objects than the free-floating sequences of limbic time, the operations involved in creating past, present and future are ultimately subjective in nature.

When the disease is still progressing, the brevity of the effect of the inner events of the sick person turns short-lived. Chaos seems to have taken hold of his ideas. He only lives in fits and starts, sometimes explosive, screams, violent gestures without reason and 
at the slightest stimulation, before plunging back into silence. It can still get lost in verbal stereotypes many times punctuated, like a broken record, in a circular time, without any range from the point of view of the extent because the words and the articulated sentences are disjoined of all directions (Gazzaniga, 2011).

In this context, it is worth recalling that the brain communicates with two codes: electrical and chemical. The firing of a given neuron is associated on the one hand with specific neurochemical changes and with the activation of patterns of various neuronal connections connecting with other neurons, which causes further specific neurochemical changes (Pąchalska, 2019). In severe, neurodegenerative brain damage, as is the case of AD, brain systems are disturbed. Depending on the extent of the neurodegeneration, they may affect one, two, three or all brain systems and related neurotransmitters (see Figure 8).

The destabilization of individual motor and sensory functions as well as language and pragmatic functions creates a new, complicated and time-varying dialectics, which is associated with the processes of neuronal loss, the breakdown of various connection patterns, and the associated metabolic and chemical activity of the brain in AD (Kropotov, 2016).

Can we imagine how an AD patient feels with such a destabilization of neural network patterns?

A healthy person can be confused in time and space in certain situations (after all, most of us experience a temporary sense of confusion in the first moments after waking up from sleep), but it is enough to find the right reference points and we immediately know where we are in time and space. In contrast, the patient with $\mathrm{AD}$ due to cognitive deterioration is unable to find such reference points and therefore his consciousness drifts in time and space (Pąchalska, Bidzan L., Bidzan M., \& Góral-Półrola, 2015).

The use of Lurias approach to brain function as well as the new neuropsychological (see also Pąchalska, 2020) and neurophysiological studies (see also Kropotov, 2016) presented above allow the reader to better understand why in the very advanced stage of Alzheimer's

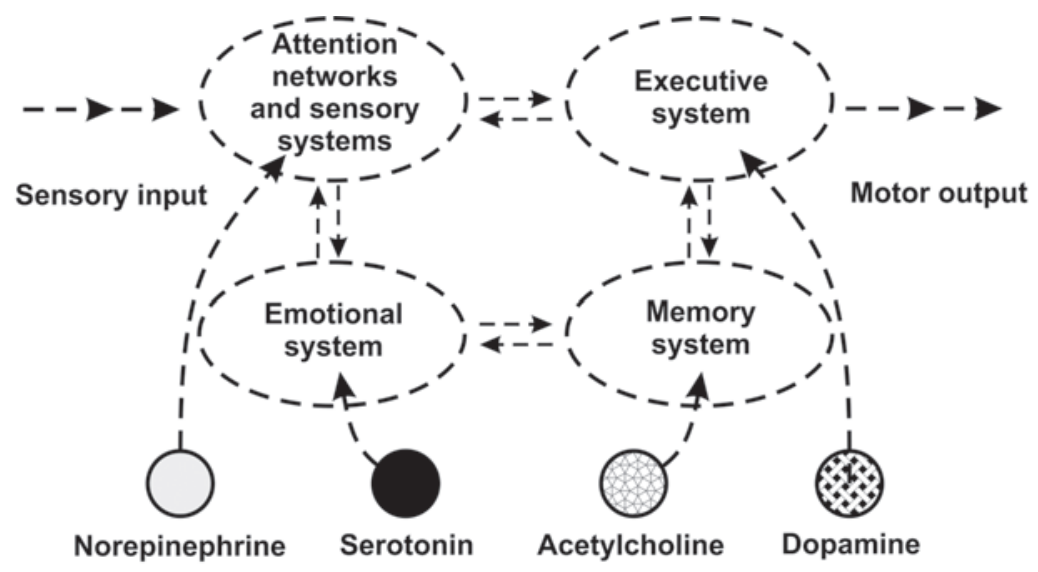

Figure 8. Deatabilization of brain systems and related neurotransmitters in AD. Reprinted from "Inner Speech in MCI and Alzheimer Disease", by M. Pąchalska, 2020, Acta Neuropsychologica, 18 (1), p. 23. Copyright 2020 by the Agencja Wydawnicza Medsportpress. Reprinted with permission 
disease, the emotional intensity suddenly seems to go away, the person no longer seems to have internal tensions, he is apathetic. He always remains frozen in the same position. Time seems to no longer run out and be endless as if the interior life had been absent. It is for him the time of eternal permanence. Perhaps it alleviates or removes the anxiety of death.

Scholars and family believe that the patient's identity is not altered (at least in the classic sense of the term), however his minimal (working), and longitudinal (autobiographical) self is disturbed (Kertesz, 2006; Mendez, 1992, 2017; Pąchalska, 2020). Because of a serious memory problem, he cannot update the knowledge of himself and others and make changes in thinking about himself and others (eg. the patient doesn't know that his wife or husband died month or year ago).

Alzheimer's disease in the final stage leads to destruction of the body. The patient is completely dependent on the help of other people and must be constantly supervised. His speech is limited to a few words. During this time, delusional self-identification disorders, difficulties in recognizing relatives may occur (Mendez, 2017). There are also (in terms of Luria, 1973) complex disorders of individual, social and cultural identity. Hallucinations and disturbances of consciousness manifested as confusion gradually appear and the patient is finally excluded from family and social life (Pąchalska, 2020).

With the course of the disease, as the extent of his emotions becomes more inaccessible to the patient. He also loses his ability to laugh (Mendez, 2017). His space for deployment narrows, but, at first, the grip on the world increases and internal tensions are increasing. Suddenly the world ends up completely escaping him, this in a catastrophic way in the sense of Thom (1996), things are reversed, internal tensions collapse, and the extensive limits disappear. Everything becomes out of the patient's reach. He no longer distinguishes what he could do in his environment, he loses the anticipatory dimension that would allow him to build a minimum of project. In a few days, the patient puts himself in a regressive position which is very difficult to reverse.

The patient is bedridden, loses vital functions, it increases the risk of infection. He may have his eyes open, but he cannot see what is happening around him. It manifests anosognosia, i. e. lack of awareness of the disease (Orfei et al., 2010). This fact is of great importance for understanding the episodes of sporadic and uncontrolled impulsive actions. Psychological time is no longer relevant, as there are deep disturbances in self-awareness (Tulving, 2002). The patient seems to hear but does not respond to the environment. He is minimally conscious, almost like the patient awaken from post traumatic coma (Pąchalska, 2020).

The eyeballs are sunken and do not close the eyelids. Physiological changes are progressing. Heart rate is weak, shallow breathing and slower. The skin is colder and more sticky, cyanosis appears on the limbs and around the mouth. The sphincter control is disturbed, resulting in stool and urine incontinence. Body temperature drops (one degree or more), blood pressure decreases, pallor and cyanosis occur, and sweating increases. The breathing becomes irregular, wheezing and coughing are heard. The most common cause of death is pneumonia (Kertesz, 2006). 


\section{Conclusion}

If the emotional intensity of what the patient experiences is enough, he remains engaged in the time of his presence in the world. The world exists, but it is perceived as hostile and is rejected by the sick $\mathrm{AD}$ person. His identity is not altered (at least in the classic sense of the term) however his minimal (working), and longitudinal (autobiographial) self is disturbed. Because of serious memory problem, he cannot update the knowledge of himself and others and make changes in thinking about himself and others. Therefore, the other, the family or a caregiver, are experienced as disturbing and hostile, intrusive and threatening to the self. The patient violently opposes all solicitations, most often closing his eyes tightly so that he no longer wants to see external reality. When the intensity collapses, he disengages from the time of his presence in the world. He is indifferent. The world no longer exists for him, he no longer reacts to the presence of others. The patient slips into an irreversible regression. What then remains of his identity? The subject has withdrawn from the world and no longer seeks to communicate with it Time no longer matters to him. The words are hidden because of progressive aphasia, linked to the disease, but also to his psychology of withdrawing from his presence in the world. Understanding of the mechanisms involved in the patient's experience of time [especially in relation to minimal (working), and longitudinal (autoographial) self] by caregivers or the families who take care of them allows them to adjust care. They limit the risk of misinterpretation as well as induce certain behavioral disorders linked to the mismatch compared to the reality of the patient.

\section{References}

Alderson-Day, B., \& Fernyhough, Ch. (2015). Inner speech: Development, cognitive functions, phenomenology, and neurobiology. Psychological Bulletin, 141(5), 931-965. https://doi.org/10.1037/ bul0000021

Araujo, H.F., Kaplan, J., \& Damasio, A. (2013). Cortical midline structures and autobiographical-self processes: an activation-likelihood estimation meta-analysis. Frontiers in Human Neuroscience, 7, 548. https://doi.org/10.3389/fnhum.2013.00548

Bergson, H. (2012). Matière et mémoire: Essai sur la relation du corps à l'esprit [Matter and memory: Essay on the relation of body to mind]. Paris: PUF.

Binswanger, L. (1998). Le problème de l'espace en psychopathologie [Space problem in psychopathology] (pp. 45-130). Toulouse: Presses Universitaires du Mirail.

Bond, R. L., Downey, L. E., Weston, P. S. J., Slattery, C. F., Clark, C. N., Macpherson, K., ... Warren, J. D. (2016). Processing of Self versus Non-Self in Alzheimer's Disease. Frontiers in Human Neuroscience, 10, 97. https://doi.org/10.3389/fnhum.2016.00097

Brainerd, C. J., \& Reyna, V.F. (2001). Fuzzy-trace theory: dual processes in memory, reasoning, and cognitive neuroscience. Advances in Child Development and Behavior, 28, 41-100. https://doi. org/10.1016/s0065-2407(02)80062-3

Brown, J.W. (2002). The self-embodying mind: Process, brain dynamics and the conscious present. Barrytown, NY: Barrytown Station Hill. 
Brown, J.W. (2004). Word-concept, verbal hallucination, and inner speech in neuropsychology. Acta Neuropsychologica, 2(3), 237-251.

Brown, J. W. (2015). Microgenetic theory and process thought. Exeter: Imprint Academic.

Brown, J.W., \& Pachalska, M. (2003). The nature of the symptom and its relevance for neuropsychology. Acta Neuropsychologica, 1(1), 1-11.

Clowes, R. (2007). A self-regulation model of inner speech and its role in the organisation of human conscious experience. Journal of Consciousness Studies, Vol. 14 (7), 59-71.

Dolcos, S., \& Albarracin, D. (2014). The inner speech of behavioral regulation: Intentions and task performance strengthen when you talk to yourself as a you. European Journal of Social Psychology, 44, 636-642.

Fama, M.E., Hayward, W., Snider, S. F., Friedman, R. B., \& Turkeltaub, P.E. (2017). Subjective experience of inner speech in aphasia: Preliminary behavioral relationships and neural correlates. Brain and Lang, 164, 32-42. https://doi.org/10.1016/j.bandl.2016.09.009

Fernyhough, C. (2013). Inner speech. In H. Pashler (Ed.), The encyclopedia of the mind (Vol. 9, pp. 418420). Thousand Oaks, California: Sage Publications. https://doi.org/10.4135/9781452257044.n155

Fontanille, J. (1998). Sémiotique du discours [Speech semiotics]. Limoges: PULIM.

Fontanille, J. (2004). Soma et séma. Figures du corps [Soma and sema. Body figures]. Paris: Maisonneuve et Larose.

Gazzaniga, M.S. (2011). Who's in charge? Free will and the science of the brain. New York: HarperCollins.

Hartog, F. (2003). Régimes d'historicité. Présentisme et expérience du temps [Historicity regimes. Presence and time experience]. Paris: Le Seuil.

Hazif-Thomas, C., Thomas, P., \& Sutter, J. (1991). Anticipation et motivation dans l'âge avancé [Anticipation and motivation in old age]. Ann Med-Psychol, 155(8), 517-522.

Hjelmslev, L. (1968). Prolégomènes à une théorie du langage [Prolegomena to a theory of language]. Paris: Minuit.

Husserl, E. (1996). Leçons pour une phénoménologie de la conscience intime du temps [Lessons for a phenomenology of the intimate consciousness of time]. Paris: PUF.

Kertesz, A. (2006). Rate of progression differs in frontotemporal dementia and Alzheimer disease. Neurology, 66 (10), 1607. https://doi.org/10.1212/01.wnl.0000226826.42746.36

Kropotov, J.D. (2016). Functional neuromarkers for psychiatry. San Diego: Academic Press, Elsevier.

Langland-Hassan, P., Faries, F. R., Richardson, M. J., \& Dietz, A. (2015). Inner speech deficits in people with aphasia. Frontiers in Psychology, 6, 528. https://doi.org/10.3389/fpsyg.2015.00528

Luria, A. R. (1973). The working brain. New York: Basic Books.

Luria, A. R. (1979). The making of mind. Cambridge; Massachusetts: Harvard University Press.

Luria, A. (1980). Higher cortical functions in man. New York: Basic Books.

Maisondieu, J. (2011). Le crépuscule de la raison [The twilight of reason]. Toulouse: Bayard.

Mendez, M. F. (1992). Delusional misidentification of persons in dementia. The British Journal of Psychiatry, 160, 414-416. https://doi.org/10.1192/bjp.160.3.414

Mendez, M.F. (2017). Early-onset Alzheimer disease. Neurologic Clinics, 35(2), 263-281. https://doi. org/10.1016/j.ncl.2017.01.005.

Minkowski, E. (2013). Le Temps vécu [The time lived]. Paris: PUF.

Miyake, A., Emerson, M. J., Padilla, F., \& Ahn J. C. (2004). Inner speech as a retrieval aid for task goals: The effects of cue type and articulatory suppression in the random task cuing paradigm. Acta Psychologica, 115 (2-3), 123-142. https://doi.org/10.1016/j.actpsy.2003.12.004 
Orfei, M. D., Varsi, A.E., Blundo, C., Celia, E., Casini, A.R., Caltagirone, C., \& Spalletta G. (2010). Anosognosia in mild cognitive impairment and mild Alzheimer's disease: Frequency and neuropsychological correlates. The American Journal of Geriatric Psychiatry, 18 (12), 1133-1140. https:// doi.org/10.1097/JGP.0b013e3181dd1c50

Pąchalska, M. (2019). Integrated self system: A microgenetic approach. Acta Neuropsychologica, 17, 349-392. https://doi.org/10.5604/01.3001.0013.6198

Pąchalska, M. (2020). Inner speech in MCI and Alzheimer disease. Acta Neuropsychologica, 18 (1), 5-25. Pąchalska, M., Bidzan, L., Bidzan, M., \& Góral-Półrola, J. (2015). Vascular factors and cognitive dysfunction in Alzheimer disease. Medical Science Monitor, 21, 3483-3489. https://doi.org/10.12659/ msm. 894550

Pąchalska, M., \& Kaczmarek, B. L. J. (2012). Alexander Romanovich Luria (1902-1977) and the microgenetic approach to the diagnosis and rehabilitation of TBI patients. Acta Neuropsychologica, 10 (3), 341-369. https://doi.org/10.5604/17307503.1023670

Pąchalska, M., MacQueen, B. D., \& Brown, J.W. (2012). Microgenetic theory: Brain and mind in time. In R. W. Rieber (Ed.), Encyclopedia of the history of psychological theories (pp. 675-708). New York: Springer. https://doi.org/10.1007/978-1-4419-0463-8_150

Pąchalska, M., MacQueen, B. D., \& Cielebąk, K. (2018). Creative potentials of microgenetic theory. Acta Neuropsychologica, 16 (2), 125-155. https://doi.org/10.5604/01.3001.0011.8320

Shergill, S. S., Brammer, M. J., Fukuda, R., Bullmore, E., Amaro Jr., E., Murray, R. M., \& McGuire, P. K. (2002). Modulation of activity in temporal cortex during generation of inner speech. Human Brain Mapping, 16 (4), 219-227. https://doi.org/10.1002/hbm.10046

Stuss, D. T., Rosenbaum, R. S., Malcolm, S., Christiana, W., \& Keenan, J.P. (2005). The frontal lobes and self-awareness. In T.E. Feinberg \& J.P. Keenan (Eds.), The lost self: Pathologies of the brain and identity (pp. 50-64). Oxford: Oxford University Press. https://doi.org/10.1093/acprof: oso/9780195173413.003.0005

Thom, R. (1996). Crise et catastrophe. La notion de crise [Crisis and disaster. The concept of crisis]. Communications, 25, 34-38.

Thomas, P., Billon, R., \& Hazif-Thomas, C. (2018). Narrativity analysis in Alzheimer's disease. In J.M. Glozman, O. S. Vindeker, I. A. Ershova, \& M. E. Permiakova (Eds.), The Fifth International Luria Memorial Congress "Lurian approach in international psychological science", KnE Life Sciences, 849-855. https://doi.org/10.18502/kls.v4i8.3342

Thomas, P., Clément, J. P., Hazif-Thomas, C., \& Leger, J. M. (2001). Family, Alzheimer's disease and negative symptoms. International Journal of Geriatric Psychiatry, 16 (2), 192-202. https://doi. org/10.1002/1099-1166(200102)16:2<192:: aid-gps301>3.0.co;2-y

Tulving, E. (2002). Chronesthesia: Awareness of subjective time. In D. T. Stuss \& R. C. Knight (Eds.), Principles of frontal lobe functions (pp. 311-325). New York: Oxford University Press.

Zilberberg, C. (2000). La structure tensive [The tensive structure]. Liège: Presse Universitaire de Liège. Zilberberg, C. (2011). Des formes de vie aux valeurs. Collection formes sémiotiques [Life forms to values. Semiotic forms collection]. Paris: PUF.

Original manuscript received February 3, 2020

Revised manuscript accepted March 18, 2020

To cite this article: Thomas, P., \& Hazif-Thomas, C. (2020). The experience of personal time in Alzheimer's disease. Lurian Journal, 1 (1), 140-158. DOI:10.15826/Lurian.2020.1.1.10 